\title{
Konsep Diri Dan Pengaruhnya Terhadap Kenakalan Remaja Pada Siswa SMK Negeri I Rembang
}

\author{
Agus Retnanto \\ STAIN Kudus, Jawa Tengah, Indonesia \\ agus.retnanto13@gmail.com
}

\begin{abstract}
Abstrak
Remaja yang sedang dalam proses transisi sering dalam keadaan yang tidak stabil dan belum matang sepenuhnya. Kenakalan remaja menunjukkan kondisi yang membahayakan. Tujuan Penelitian adalah: (1) Ingin mengetahui konsep diri siswa di SMK N I Rembang Tahun Pelajaran 2014/2015 (2) Ingin mengetahui sikap perilaku kenakalan remaja pada siswa di SMK N I Rembang Tahun Pelajaran 2014/2015 (3) Ingin mengetahui pengaruh konsep diri terhadap kenakalan remaja pada siswa di SMK N I Rembang Tahun Pelajaran 2014/2015. Penelitian yang penulis lakukan termasuk jenis penelitian eksperimen dengan rumus yang dipakai untuk menganalisis hasil dari pengumpulan data penelitian di atas dalam penelitian ini adalah rumus Analisis Regresi. Hasil penelitian dapat disimpulkan sebagai berikut: (1) Persentase rata-rata angket konsep diri menunjukkan 80,8\%. Artinya konsep diri siswa menunjukkan kategori tinggi/baik, (2) Persentase angket kenakalan remaja menunjukkan $81,3 \%$. Artinya kenakalan remaja siswa dalam katagori agak rendah, (3) F hitung $=192,56>\mathrm{F}$ tabel $5 \%(1 ; 47)=4,05$ artinya antara variabel X (konsep diri) dan variabel Y (kenakalan remaja) berpengaruh secara signifikan pada taraf 5\%. Maka hipotesis penelitian yang berbunyi: Ada pengaruh positif yang signifikan konsep diri terhadap kenakalan remaja pada siswa SMK N I Rembang tahun pelajaran 2014/2015, diterima karena teruji kebenarannya, besarnya pengaruh $81,1 \%$.
\end{abstract}

Kata Kunci: Konsep diri; kenakalan remaja. 


\begin{abstract}
Teenagers who are in the process of transition are often unstable and immature. Juvenile delinquency shows dangerous conditions. The purposes of the study are: (1) Want to know the self-concept of students in SMK NI Rembang Lesson Year 2014/2015 (2) Want to know the behavior behavior of juvenile delinquency in students at SMK NI Rembang Lesson 2014/2015 (3) Want to know the influence of self concept against juvenile delinquency in students at SMK NI Rembang Lesson Year 2014/2015. Research carried out includes the type of Experimental research with the formula used to analyze the results obtained from the research data above in this study is the Regression Analysis formula. The results of the study can be summarized as follows: (1) The average percentage of self concept questionnaire shows $80.8 \%$. This means self-concept students show high category / good, (2) The percentage of juvenile delinquency questionnaire showed $81.3 \%$. This means that juvenile delinquency of students in the category is rather low, (3) $F$ arithmetic $=192.56>F$ table $5 \%(1: 47)=4.05$ means that between variable $X$ (self concept) and variable Y (juvenile delinquency) significantly influence at 5\% level. Then the research hypothesis reads: There is a significant positive effect of self-concept of juvenile delinquency in students of SMK N I Rembang academic year 2014/2015, accepted because of its validity, with an influence of $81.1 \%$.
\end{abstract}

Keywords: Self concept; juvenile delinquency.

\title{
A. Pendahuluan
}

Remaja merupakan generasi penerus bangsa yang diharapkan dapat menggantikan generasi-generasi terdahulu dengan kwalitas kinerja dan mental yang lebih baik. Dengan adanya program pendidikan dasar, menengah dan tinggi diharapkan dapat menghasilkan sumber daya manusia yang berkualitas tinggi.

Remaja yang sedang dalam proses transisi dari masa anak menuju kedewasaan sering dalam keadaan yang tidak stabil dan belum matang sepenuhnya sebagaimana harapan orang tua, pendidik dan masyarakat. Pada masa transisi tersebut banyak remaja yang 


\section{Konsep Diri Dan Pengaruhnya Terhadap Kenakalan Remaja ...}

mengalami goncangan batin yang menggelisahkan diri mereka, baik dari segi internal yaitu ketegangan batin dan gangguan kejiwaan serta dari segi eksternal yaitu menghendaki banyaknya tuntutan sosial, sanksi-sanksi dan tekanan sosial atau masyarakat yang mereka anggap melawan dorongan kebebasan mutlak dan ambisi yang sedang menggebu-bebu. Kedua aspek ini sangat mempengaruhi dan menentukan ciri individu dalam bertingkah laku terhadap masyarakat sekitar. Oleh karena itu kita harus berupaya untuk memahami bagaimana pertumbuhan dan perkembangan yang dialami para remaja. Memahami anak remaja berarti harus memahami berbagai masalah dan kesulitan yang dialaminya, Dengan pemahaman itu maka akan membantu kita sebagai orang tua, pendidik dan masyarakat lain untuk memecahkan masalah kenakalan remaja agar tidak berkepanjangan dan bertambah parah.

Fenomena kenakalan remaja sebagaimana diberitakan berbagai media menunjukkan kondisi yang membahayakan. Berbagai macam kenakalan remaja yang ditunjukkan akhir-akhir ini adalah perkelahian, mabuk-mabukan, pemerasan, pencurian, perampokan, penganiayaan, dan penyalahgunaan obat-obatan (narkoba), semakin hari semakin meningkat kwalitas dan kwantitasnya. Seperti yang diberitakan harian "Jawa Pos", tanggal 20 November 2014, dalam artikel dengan judul "Mampir Warung, Empat Pelajar Diamankan”. Berdasarkan observasi dan wawancara penulis dengan guru Bimbingan dan Konseling, gejala yang nampak pada siswa SMKN I Rembang, khususya Klas II adalah membolos, merokok, menyontek terlambat datang, membuat gaduh saat pelajaran, berpakaian tidak rapi, nongkrong ditempat umum pada jam pelajaran.

Kecenderungan kenakalan remaja yang terjadi disekolah sekolah lanjutan maupun dilingkungan lain, dapat diibaratkan sebagai penyakit menular yang sulit disembuhkan dari masa kemasa dan banyak faktor yang mempengaruhinya. (Kartono, 2008: 109) mengatakan bahwa kenakalan remaja disebabkan oleh dua faktor yaitu faktor internal dan faktor eksternal. Faktor internal terjadi lewat proses internalisasi diri yang keliru oleh anak-anak remaja dalam menanggapi masyarakat sekitarnya dan semua pengaruh dari luar. Tingkah laku mereka itu merupakan reaksi yang salah atau irasional dari proses belajar dan ketidakmampuan mereka dalam 
melakukan adaptasi terhadap lingkungan sekitar. Faktor eksternal dikenal pula sebagai pengaruh alam sekitar, faktor sosial atau faktor sosiologis yaitu semua perangsang dan pengaruh luar yang menimbulkan tingkah laku tertentu pada anak remaja.

Konsep diri merupakan salah satu faktor internal yang dapat mempengaruhi tingkah laku individu termasuk kenakalan. (Burns, 2003: 209) menyatakan, sewaktu lingkungan anak yang sedang tumbuh itu meluas, isi dalam konsep dirinya juga berkembang meluas termasuk hal-hal pemilihan teman, nilai-nilai dan orang yang disayangi melalui proses identifikasi. Individu tidak dilahirkan dengan konsep diri. Konsep diri berasal dan berakar pada pengalaman masa kanak-kanak dan berkembang, terutama sebagai akibat dari hubungan individu dengan orang lain.

Konsep diri menurut (Calhoun dan Joan Rose, 2003: 72-74) mencakup dua yaitu konsep diri negatif dan konsep diri positif. Konsep diri negatif muncul karena pandangan seseorang tentang dirinya benar-benar tidak teratur, dia tidak tahu apa kekuatan dan kelemahan dirinya atau apa yang dia hargai dalam hidupnya, dan kosep diri yang terlalu teratur atau kaku.

Salah satu ciri individu yang memiliki kosep diri yang negatif adalah individu yang mudah marah dan naik pitam serta tidak tahan terhadap kritikan yang diterimanya, dengan kata lain individu kurang menerima peraturan atau norma yang ditetapkan, sehingga ada sifat memberontak pada dirinya yang menentang aturan tersebut. Dalam hal ini apabila terjadi dalam diri remaja maka akan menimbukan perilaku yang menyimpang pada diri remaja yang kemudian lebih banyak disebut kenakalan remaja. Sedangkan konsep diri positif, individu dapat memahami dan menerima sejumlah fakta yang sangat bermacam-macam tentang dirinya sendiri, dia juga dapat menerima orang lain. Salah satu ciri individu yang memiliki konsep diri positif selalu memiliki ide yang diberikan kepada kehidupannya dan bagaimana seharusnya mendekati dunia, sehingga aturan atau norma yang ada iapun memahami, menghargai serta mematuhinya. Dengan demikian dapat diasumsikan bahwa konsep diri mempengaruhi kenakalan remaja. 
Hasil pengamatan penulis, kenakalan remaja yang terdapat di SMK N I Rembang masih dalam batas kewajaran seperti (tidak masuk tanpa ijin, membolos, membuat gaduh saat pelajaran, merokok, berkelahi, minum-minuman keras dan nongkrong ditempat umum). Siswa yang melakukan tindak kenakalan akan mendapat sanksi sesuai dengan peraturan sekolah. Kenakalan kebanyakan dilakukan oleh siswa yang mempunyai nilai akademik dibawah rata-rata. Mayoritas siswa yang melakukan kenakalan SMKN I Rembang adalah siswa klas II, terutama siswa jurusan Kontruksi Perkayuan, karena siswa yang mendaftar di jurusan tersebut adalah siswa yang tidak diterima dijurusan Mesin dan jurusan Otomotif karena memang UAN-nya rendah. Dari pengamatan penulis masih banyak siswa SMKN I Rembang yang melakukan pelanggaran, meskipun sekolah sudah berusaha keras menegakkan kedisiplinan dan memberikan sanksi bagi yang melanggar peraturan sekolah.

\section{Metode Penelitian}

Penelitian yang penulis lakukan termasuk jenis penelitian eksperimen dengan rumus yang dipakai untuk menganalisis hasil dari pengumpulan data penelitian di atas dalam penelitian ini adalah rumus Analisis Regresi. Populasi dalam penelitian di SMK N 1 Rembang, sebanyak 723 siswa, yang terdiri dari kelas X sampai kelas XII, dengan jumlah 20 kelas. Kelas XI ada 318 siswa.

Tabel 1. Populasi Penelitian

\begin{tabular}{clccc}
\hline No & Jurusan & Laki-laki & Perempuan & Jumlah \\
\hline 1 & Tehnik Mesin Perkakas & 108 & - & 108 \\
\hline 2 & Tehnik Mekanik Otomotif & 68 & 1 & 69 \\
\hline 3 & Kontruksi Perkayuan & 60 & 5 & 65 \\
\hline 4 & Tehnik Gambar Bangunan & 30 & 7 & 37 \\
\hline 5 & Tehnik Komputer Jaringan & 28 & 11 & 39 \\
\hline & Jumlah & 294 & 24 & 318 \\
\hline
\end{tabular}

Penelitian ini mengambil teknik Purposive random sampling. Purposive random sampling adalah teknik penentuan sampel dengan random yang dilakukan dengan tujuan tertentu, yaitu sengaja memilih kelas XI agar dapat melakukan penelitian dengan leluasa tanpa mengganggu aktifitas kelas yang tengah mempersiapkan ujian nasional khususnya kelas XII. Tidak memilih kelas XI karena masih 
dalam rangka penyesuaian. Penulis menggunakan sampling ini karena mengambil 2 variabel. Variabel $\mathrm{X}$ adalah konsep diri, dan variabel Y adalah sikap kenakalan remaja.

Tabel 2. Sampel Penelitian

\begin{tabular}{clcc}
\hline No & Jurusan & Populasi & Sampel (15\%) \\
\hline 1 & Tehnik Mesin Perkakas & 108 & 16 \\
\hline 2 & Tehnik Mekanik Otomotif & 69 & 11 \\
\hline 3 & Kontruksi Perkayuan & 65 & 9 \\
\hline 4 & Tehnik Gambar Bangunan & 37 & 6 \\
\hline 5 & Tehnik Komputer Jaringan & 39 & 5 \\
\hline & Jumlah & 318 & 47 \\
\hline
\end{tabular}

Metode pengumpulan data yang digunakan dalam penelitian ini adalah skala psikologis yaitu skala konsep diri yang berbentuk kuesioner/sejumlah pertanyaan untuk memperoleh data yang dibutuhkan dalam penelitian. Kuesioner adalah sejumlah pertanyaan tertulis yang digunakan untuk memperoleh informasi oleh responden dalam arti laporan tentang pribadinya atau hal-hal yang ia ketahui (Arikunto, 1992: 10).

\section{Kerangka Berpikir.}

Kenakalan ramaja yang dimaksud adalah bentuk pelanggaran-pelanggaran tata tertib atau aturan yang telah dilaksanakan disekolah sehingga mengganggu proses pembelajaran disekolah. Konsep diri adalah pandangan menyeluruh tentang identitas diri sendiri baik mengenahi kepribadian, nilai-nilai kehidupan, prinsip hidup, moralitas, kelemahan diri dan segala aspek lainnya yang terbentuk dari pengalaman dan interaksinya. Konsep diri penting artinya bagaimana individu memandang diri dan dunianya, mempengaruhi tidak hanya ia berperilaku, tetapi juga tingkat kepuasan yang diperoleh dalam hidup. Individu yang memandang diri dan dunianya dari segi positif dan penyenangkan pada umumnya berperilaku efektif dalam berbagai situasi. Orangorang yang seperti itu kebanyakan puas terhadap dirinya dan pengalaman hidupnya. Individu-individu yang memandang diri dan dunianya dari kaca mata suram, maka akan cenderung tidak mencoba pengalaman-pengalaman hidup baru karena mereka selaku 


\section{Konsep Diri Dan Pengaruhnya Terhadap Kenakalan Remaja ...}

khawatir akan menemui kegagalan, individu-individu seperti ini kebanyakana tidak bahagia dalam hidupnya.

Proses terbentuknya konsep diri dipengaruhi oleh hal-hal yang sifatnya bawaan dan belajar (baik dalam lingkungan keluarga, sekolah, maupun masyarakat), proses ini berlangsung dari interaksi individu dengan orang lain. Konsep diri terbentuk dari pandanganpandangan orang lain terhadap individu, dan juga dari rekontruksirekontruksi aktif individu terhadap pandangannya, terhadap proses interaksi.

Dari uraian tersebut penulis menyimpulkan bahwa konsep diri menentukan bagaimana individu berperilaku, bagaimana individu berinteraksi terhadap dengan orang-orang dan situasi. Perilaku individu ada yang positif dan ada yang negatif, dalam artian perilaku yang tidak merugikan orang lain yaitu positif, sedang yang negatif yaitu perilaku yang merugikan orang lain, seperti halnya perilaku nakal. Dengan demikian diasumsikan bahwa konsep diri negatif akan membentuk perilaku negatif pula. Melihat analisis tersebut maka dapat ditarik kesimpulan bahwa bahwa konsep diri dapat mempengaruhi kenakalan remaja, karena salah satu ciri konsep diri negatif yaitu tidak puas terhadap dirinya dan berilaku merugikan orang lain merupakan salah satu faktor penyebab kenakalan remaja.

\section{B. Pembahasan}

\section{Konsep Diri.}

Menurut William D. Brooks (dalam Jallaludin Rahmad, 2005: 99) konsep diri adalah pandangan dan perasaan kita tentang diri kita. Konsep diri ini meliputi dua komponen yaitu komponen kognitif dan afektif yang dalam psikologi sosial disebut sebagai citra diri dan harga diri. Komponen kognitif merupakan pengetahuan dari "siapa saya" yang memberi gambaran tentang diri individu tersebut. Gambaran diri (self picture) tersebut akan membentuk citra diri (self image). Komponen kognitif merupakan data yang bersifat obyektif. Sementara komponen efektif merupakan penilaian individu terhadap dirinya. Penilaian tersebut akan membentuk penerimaan terhadap diri (self acceptance) serta harga diri individu, ini berarti komponen efektif merupakan data subyektif. 
Beberapa pendapat para ahli tentang konsep diri tersebut dapat disimpulkan bahwa konsep diri adalah pandangan menyeluruh tentang totalitas diri sendiri baik mengenahi kepribadian nilai-nilai kehidupan, prinsip hidup, moralitas, kelemahan diri dan segala aspek lainnya yang terbentuk dari pengalamam dan interaksinya.

Konsep diri yang dimiliki oleh setiap individu ada dua jenis yaitu konsep diri positif dan konsep diri negatif. Konsep diri positif tidak berdasarkan pada kebanggaan yang besar tentang diri yang menyebabkan menjadi sombong, congkak, angkuh melainkan lebih berdasar pada penerimaan diri yang mengarahkannya pada kerendahan hati dan kedermawanan. Orang yang berkonsep diri negatif berkecenderungan menunjukkan sikap mengasingkan diri, malu-malu dan menarik diri. Individu yang berkonsep diri negatif tidak ada perhatian dan kasih sayang terhadap orang lain diluar dirinya. Individu yang mempunyai konsep diri negatif hanya memperhatikan dirinya sendiri sepanjang waktu, tidak pernah merasa puas, selalu takut kehilangan sesuatu, takut tidak diakui, iri kepada mereka yang mempunyai kelebihan. Keadaan ini berakar pada tiadanya kesenangan pada diri sendiri., dan mempunyai sikap egois sebagai kompensasi diri yang berlebihan.

Menurut William D. Brooks dan P Emmert (dalam Jalaludin Rakhmat, 1999: 103) ada lima tanda orang yang mempunyai konsep diri negatif yaitu:

a. Peka terhadap kritik, yaitu tidak tahan terhadap kritik yang diterimanya dan mudah marah, hal itu berarti dilihat dari faktor yang mempengaruhi dari individu tersebut belum dapat mengendalikan emosinya sehingga kritikan dianggap hal yang salah dan membuat dirinya marah atau naik pitam.

b. Responsif sekali terhadap pujian, yaitu tidak dapat menyembunyikan situasi pada waktu menerima pujian, segala yang ada pada dirinya menjadi pusat perhatian, ia mengeluh, mencela, merendahkan orang lain dan sebagainya.

c. Sikap Hiperkritis (melebihi) yaitu ia tidak pandai dan tidak sanggup mengungkapkan penghargaan atau kelebihan orang lain. 


\section{Konsep Diri Dan Pengaruhnya Terhadap Kenakalan Remaja ...}

d. Cenderung merasa tidak disenangi orang lain yaitu merasa tidak diperhatikan, menganggap orang lain sebagai musuh , berarti individu tersebut akan merasa rendah diri atau bahkan berperilaku yang tidak disenangi, misalnya membenci, mencela atau berperilaku yang melibatkan fisik contohnya berkelahi.

e. Bersikap pesimis terhadap kompetisi seperti terungkap dalam keengganannya untuk bersaing dengan orang dalam meraih prestasi. Diatas telah dijelaskan bahwa kenakalan siswa pada SMKN I Rembang dilakukan kebanyakan oleh siswa jurusan Kontruksi Kayu yang prestasi akademiknya kurang dari ratarata, berarti siswa tersebut kurang minat bersaing dalam berprestasi.

Sementara konsep diri positif tercermin pada:

a. Orang yang terbuka. Individu yang mempunyai konsep diri positif cenderung menyenangi dan menghargai diri mereka sendiri, sebagaimana sikap mereka terhadap orang lain. Penerimaan diri sebagai seseorang yang sama berharganya dengan orang lain meskipun terdapat perbedaan-perbedaan dalam bakat dan sifat yang spesifik.

b. Orang yang tidak mengalami hambatan untuk berbicara dengan orang lain, bahkan dalam situasi yang masih asing sekalipun.

c. Orang yang cepat tanggap terhadap situasi sekelilingnya. Individu yang mempunyai konsep diri positif memiliki rasa aman dan percaya diri yang tinggi, mampu lebih menerima dan memberi pada orang lain, mempunyai sensitifitas terhadap kebutuhan orang lain. Memiliki keyakinan dan kepercayaan diri untuk menanggulangi masalah bahkan dihadapkan pada kegagalan sekalipun sanggup dihadapi dengan jiwa besar.

Adapun faktor-faktor yang mempengaruhi konsep diri adalah sebagai berikut:

a. Orang lain.

Seseorang mengenal dirinya dengan orang lain terlebih dahulu. Konsep diri seorang individu terbentuk dari bagaimanapenilaianorang lain mengenahi dirinya. Tidak semua orang berpengaruh pada diri seseorang, Yang paling berpengaruh 
adalah orang-orang yang disebut significant others, yakni orangorang yang sangat penting bagi seseorang. Ketika kecil significant others adalah orang tua dan saudaranya. Dari merekalah seseorang membentuk konsep dirinya. Seorang individu akan menilai dirinya positif ketika yang bersangkutan mendapatkan senyuman, penghargaan, pelukan ataupun pujian. Sebaliknya seorang akan menilai dirinya negatif jika memperoleh kecaman, cemoohan maupun makian. Dalam perkembangannya, significant others meliputi semua orang yang mempengaruhi perilaku, pikiran dan perasaan seseorang (Dewey dan W. J Humber, 1966: 105)

b. Kelompok acuhan (reference group).

Dalam kehidupannya, setiap orang sebagai anggota masyarakat menjadi anggota berbagai kelompok. Setiap kelompok memiliki norma-norma sendiri. Diantara kelompok tersebut, ada yang disebut kelompok acuhan, yang membuat individu mengarahkan perilakunya sesuai dengan norma dan nilai yang dianut kelompok tertentu. Kelompok inilah yang mempengaruhi konsep diri seseorang.

Slameto (1984: 184) berpendapat bahwa konsep diri sebagai suatu produk sosial dibentuk melalui proses internalisasi dan pengalaman spikologis. Pengalaman-pengalaman psikologis ini merupakan hasil eksplorasi individu terhadap lingkungan fisiknya, afleksi dari dirinya sendiri yang diterma dari orang-orang berpengaruh terhadap dirinya.

Hal tersebut senada dengan pendapat Singgih D Gunarsa (Gunarsa, 1995: 237) bahwa konsep diri terdiri atas tahapantahapan yaitu konsep diri primer dan konsep diri sekunder. Konsep diri primer terbentuk berdasarkan kenyataan pengalaman individu dengan lingkungan terdekatnya yaitu keluarga. Konsep diri sekunder terbentuk setelah anak tumbuh maupun berinteraksi dengan lingkungan luar sehingga terbentuk konsep diri baru yang lebih berkembang dari apa yang diperoleh dari lingkungan terdahulu.

Jadi jelas kiranya konsep diri terbentuk dari hasil kerja sama antara pembentukan konsep diri pada tahap primer dengan tahap sekunder, namun terbentuknya konsep diri sekunder ditentukan oleh konsep diri primernya. Dengan demikian dapat disimpulkan 


\section{Konsep Diri Dan Pengaruhnya Terhadap Kenakalan Remaja ...}

bahwa semakin bertambah luasnya pengalaman yang diperoleh individu, maka akan semakin bertambah pula aspek yang akan turut mewarnai konsep diri.

Setelah konsep diri terbentuk dengan mengalami beberapa tahap yaitu tahap primer dan sekunder, maka konsep diri juga mengalami perkembangan, pada saat bayi mulai mengenal dan membedakan dirinya dengan orang lain, perkembangan kondep diri terpacu dengan cepat dengan perkembangan bicara.

Tahap selanjutnya adalah anak pada saat dimana keluarga mempunyai peran yang penting dalam membantu perkembangan konsep diri terutama pada pengalaman masa kanak-kanak. Suasana keluarga yang saling menghargai dan mempunyai pandangan yang positif akan membangun kreatifitas anak, menghasilkan perasaan positif dan berarti.

Lazimnya remaja dianggap mulai pada anak usia 13 tahun keatas, anak secara seksual menjadi matang dan berakhir saat ia mencapai usia matang secara hukum. Namun penelitian tentang perubahan perilaku, sikap dan nilai-nilai sepanjang masa remaja tidak hanya menunjukkan bahwa setiap perubahan terjadi lebih cepat pada awal masa remaja, tetapi juga menunjukkan bahwa perilaku sikap dan nilai-nilai pada awal masa remaja berbeda dengan pada akhir masa remaja.

Dengan demikian secara umum masa remaja dibagi menjadi dua bagian, yaitu awal masa remaja dan akhir masa remaja. Garis pemisah antara awal masa remaja dan akhir masa remaja terletak kira-kira sekitar usia 17 tahun, usia saat rata-rata setiap remaja memasuki sekolah menengah tingkat atas. Masa remaja merupakan masa yang potensial untuk mengembangkan konsep diri, sebab masa remaja adalah masa yang penuh dengan tekanan sehingga memungkinkan individu menemukan identitas dirinya. Dengan mencoba berbagai peran, remaja berharapkan bahwa ia mempunyai kesempatan untuk mengembangkan konsep diri. Apabila pada masa remaja individu tidak mendapat kesempatan untuk mengembangkan diri dan menyesuaikan diri dengan tugas-tugas perkembangannya, maka ia juga kehilangan kesempatan untuk mengembangkan konsep dirinya. 


\section{Kenakalan Remaja.}

Kenakalan remaja atau Juvenile delinqueney mempunyai makna yang tertuju kepada suatu masa tertentu, yaitu masa remaja sekitar usia 13-15 tahun sampai dengan 21 tahun. (Simanjuntak, 1998: 64) menyatakan bahwa yang dimaksud dengan kenakalan remaja adalah perbuatan remaja yang melanggar norma-norma, baik norma sosial, norma hukum, norma kelompok, mengganggu ketentraman masyarakat, sehingga yang berwajib mengambil suatu tindakan pengasingan. Bimo Walgito (dalam Sudarsono, 2003: 18) merumuskan arti selengkapnya dari kenakalan remaja yaitu, tiap perbuatan jika perbuatan tersebut dilakukan oleh orang dewasa, maka itu merupakan kejahatan, jadi perbuatan yang melanggar hukum, yang dilakukan oleh anak khususnya anak remaja. Fuad Hasan (dalam Sudarsono, 2003: 81) merumuskan bahwa kenakalan remaja adalah perbuatan anti sosial yang dilakukan oleh anak remaja yang bilamana dilakukan orang dewasa diklasifikasikan sebagai tindak kejahatan.

Pandangan diatas mengarah bahwa ada perbedaan antara kenakalan remaja dengan tindak kejahatan atau kriminal. Berdasarkan uraian tentang kenakalan remaja diatas, penulis menyimpulkan yang dimaksud dengan kenakalan remaja adalah setiap perbuatan yang dilakukan oleh remaja atau dalam fase usia remaja yang melanggar norma-norma, baik norma sosial, norma hukum, maupun norma kelompok, serta menggganngu ketentraman masyarakat. Tindak kejahatan adalah perbuatan yang dilakukan oleh orang dewasa yang melanggar norma-norma, baik norma sosial, norma hukum, maupun norma kelompok, serta mengganggu ketentraman sosial.

Batasan kenakalan remaja yang akan diteliti adalah bentuk pelanggaran-pelanggaran tata tertib atau aturan yang telah dilaksanakan disekolah sehingga mengganggu proses pembelajaran disekolah yaitu membolos, merokok, menyontek, terlambat datang, membuat gaduh saat pelajaran, berkelahi, minum-minumam keras dan penyimpangan seks.

Jansen (dalam Sarlito 2003: 201) membagi kenakalan remaja menjadi empat jenis yaitu: (a) Kenakalan yang menimbulkan korban 


\section{Konsep Diri Dan Pengaruhnya Terhadap Kenakalan Remaja ...}

fisik pada orang lain seperti: perkelahian, perkosaan, perampokan, pembunuhan dan lain-lain, (b) Kenakalan yang menimbulkan korban materi: perusakan, pencurian, pencopetan, pemerasan dan lain-lain, (c) Kenakalan sosial yang tidak menimbulkan korban dipihak lain: pelacuran, penyalahgunaan obat, merokok, dan lain-lain, (d) Kenakalan yang melawan status: misalnya mengingkari status sebagai anak pelajar dengan cara membolos, mengingkari status sebagai anak (dalam rumah tangga) dengan cara minggat dari rumah, membangkang perintah orang tua dan sebagainya. Pada usia mereka perilaku-perilakunya memang belum melanggar hukum dalam arti yang sesungguhnya karena yang dilanggar adalah status-status dalam lingkungan primer (keluarga) dan sekunder (sekolah) yang memang tidak diatur oleh hukum secara terinci. Akan tetapi kalau kelak remaja ini dewasa, status-status ini dapat dilakukan terhadap atasannya dikantor atau petugas hukum di masyarakat (Wirawan S, 2003: 200).

Gunarsa (2003: 200) menggolongkan kenakalan remaja dalam dua bentuk. Pertama, kenakalan yang bersifat a-moral dan asosial. Kedua adalah kenakalan yang melanggar hukum. Bedasarkan keduanya, bentuk kenakalan dapat diuraikan sebagai berikut: (a) Berbohong, memutar balikkan kenyataan dengan tujuan menipu orang tua atau menutupi kesalah-an, (b) Kabur, pergi meninggalkan rumah tanpa ijin orang tua atau menentang perintah orang tua, (c) Membolos, pergi meninggalkan sekolah tanpa sepengetahuan pihak sekolah, (d) Keluyuran, pergi sendiri maupun berkelompok tanpa tujuan dan menimbulkan perbuaran iseng yang negatif, (e) Memiliki dan membawa benda yang membahayakan orang lain, sehingga terangsang untuk mempergunakannya, misalnya: pisau, pistol, clurit dan lain-lain, (f) Bergaul dengan teman yang memberi pengaruh buruk; sehingga mudah terjerat dalam perkara yang benar-benar kriminal, (g) Berpesta pora tanpa pengawasan, sehingga akan timbul tindakantindakan yang kurang bertanggung jawab (a moral dan a sosial), (h) Membawa buku-buku cabul dan kebiasaan mempergunakan bahasa yang tidak sopan, tidak senonoh seolah-olah menggambarkan kurang perhatian dan pendidikan dari orang dewasa, (i) Secara berkelompok makan dirumah makan tanpa membayar, atau naik 
kendaraan umum tanpa membayar, (j) Turut dalam pelacuran atau melacurkan diri, baik dengan alasan kesulitan ekonomi maupun tujuan lainnya, (h) Berpakaian tidak pantas dan minum-minuman keras atau ganja.

Kenakalan yang melanggar hukum diselesaikan melalui hukum dan disebut dengan istilah kejahatan. Kejahatan itu dapat diklasifikasikan sesuai dengan berat ringannya pelanggaran kejahatan tersebut, misalnya; (a) Perjudian dengan berbagai bentuknya, (b) Pencurian dengan kekerasan maupun tanpa kekerasan, pencopperampasan dan penjambretan, (c) Penggelapan barang, (d) Penipuan dan pemalsuan, (e) Pelanggaran tata susila, menjual gambar-gambar porno dan film porno, perkosaan, (f) Pemalsuan uang dan pemalsuan surat-surat penting, (g) Tindakantindakan anti sosial; perbuatan yang merugikan milik orang lain, (h) Percobaan pembunuhan, (i) Me-nyebabkan kematian orang, turut tersangkut dalam pembunuhan, (j) Pembunuhan, (k) Pengguguran kandungan, (l) Penganiayaan berat yang meng-akibatkan kematian seseorang.

Dari uraian diatas penulis menyimpulkan bahwa kenakalan yang melanggar hukum disebut kejahatan dan yang menangani pihak pengadilan hukun, apabila kenakalan tersebut dilakukan oleh pelajar maka penanganannya melalui sanksi sekolah dengan merekomendasikan pada pihak lain yang lebih berwenang yaitu pihak kepolisian atau hukum yang ada.

Timbulnya tindakan kenakalan adalah berawal dari masalah yang dialaminya tidak dapat dipecahkan atau diselesaikan. Baik itu masalah yang menyangkut dirinya sendiri dalam masa perkembangan dan masa pertumbuhannya, maupun masalah yang menyangkut dengan lingkungannya, yaitu diri teman sebaya, lingkungan keluarga khususnya dengan orang tua maupun dengan masyarakat luas. Masalah-masalah yang berkaitan dengan diri ndividu itu sendiri misalnya: remaja ingin selalu berpenampilan rapi dan mempunyai wajah yang cantik, remaja yang kesulitan dalam menyesuaikan dirinya dengan nilai-nilai yang ada, ingin menjadi populer dan pujaan diantara yang lainnya sehingga bila temantemannya tersebut menyepelekannya maka akan timbul rasa kecewa. 
Pergaulan dengan orang tua pun tidak selalu berjalan dengan baik dan lancar. Orang tua yang memberikan peratutan-peraturan pada anak agar mereka tidak betingkah-laku menurut kemauan orang tua, hal itu dirasakan oleh remaja sebagai suatu kekangan. Masalah lain adalah yang berhubungan dengan ekonomi yaitu pemenuhan kebutuhan, baik kebutuhan yang berkaitan dengan pendidikan atau sekolah maupun kebutuhan lainya.

Pergaulan dengan masyarakat luaspun harus dilakukan oleh remaja dengan baik. Bagaimana bersikap dan bertingkah laku yang baik dan wajar dihadapan orang dewasa merupakan suatu hal yang harus dipelajari oleh remaja. Bila remaja tidak bisa berperan dengan baik sesuai dengan tuntutan lingkungan sekitar maka akan timbul permasalahan.

Akibat permasalahan-permasalahan yang timbul tersebut lama kelamaan bila tidak dapat diatasi akan menimbulkan gejalagejala tingkah laku tertentu. Tingkah laku yang pertama belum menjurus pada tingkah laku yang negatif yang kuat tetapi masih dalam taraf yang wajar dan bisa segera diatasi. Sebaliknya bila tidak segera memperoleh bantuan dari orang dewasa maka tingkah laku yang negatif tersebut berkembang pada gejala tingkah laku yang agresif, yaitu tingkah laku sosial yang menyimpang dan bersifat merusak, melanggar norma dan peraturan.

Simanjuntak mengemukakan tentang gejala yang dapat memperlihatkan ha-hal yang mengarah pada masalah"Juventle delinquenecy" meliputi: (a) Anak-anak yang tidak disukai oleh temantemannya sehingga anak tersebut menyendiri, (b) Anak yang sering menghindarkan diri dari tanggungjawab dirumah atau disekolah, (c) Anak-anak yang sering mengeluh, dalam arti bahwa mereka mengalami masalah yang oleh anak itu sendiri tidak sanggup mencari pemecahannya, (d) Anak-anak yang mengalami phobia dan gelisah dalam bentuk melewati batas yang berbeda dengan ketakutan anak-anak normal, (e) Anak-anak yang suka berbohong, (f) Anak-anak yang sering menyakiti dan mengganggu temantemannya baik disekolah maupun dirumah, (g) Anak-anak yang menyangka bahwa semua guru mereka dengan sengaja menghambat mereka, (h) Anak-anak yang tidak sanggup memusatkan perhatian dan pemikiran mereka (Simanjuntak, 1989: 66). 
Seperti apa yang telah diuraikan diatas bahwa tingkah laku yang negatif masih bersifat wajar dan tidak mengganggu masyarakat atau lingkungan sekelilingnya yang terus menerus akan mengakibatkan tingkah laku yang lebih buruk lagi dan mengganggu lingkungan sekelilingnya. Kenalakan remaja biasanya dikaitkan dengan agresifitas atau hiperaktivisme, misalnya: bertindak kasar sehingga menyakiti hati orang lain, suka berkelahi, membuat kegaduhan dalam masyarakat atau sekolah, mengolok-olok secara berlebihan, mengabaikan perintah, melanggar atau merusak peraturan, sangat mementingkan diri sendiri, suka menyakiti yang lebih kecil, pendendam, suka melanggar kehormatan seks lawan jenis dan semacamnya. Diantara gejala umum tingkahlaku bermasalah tarap pasif adalah sering menyendiri dan melamun, apatis, tidak bergairah, sangat mudah kecewa, sangat mudah untuk menuruti sesuatu meskipun sebenarnya dia tidak suka, sangat merasa rendah diri, mudah bingung dan sangat mudah menjadi panik.

Perubahan-perubahan sosial masyarakat membawa dampak dan pengaruh terhadap perkembangan anak baik dalam lingkungan keluarga maupun lingkungan sekolah, hal tersebut dapat dibuktikan dengan meningkatnya kenakalan remaja dan merebaknya perkelahian antar pelajar diberbagai kawasan. Dari berbagai kalangan menyebutkan bahwa penyebab kebrutalan/kenakalan remaja disebabkan karena faktor yang sangat mendukung terjadinya kenakalan remaja tersebut. Untuk mengetahui lebih jelas mengenahi faktor-faktor yang menyebabkan anak remaja melakukan kenakalan, maka penulis mengemukakan pendapat dari berbagai ahli sebagai berikut: Faktor kenakalan remaja menurut Singgih D Gunarsa (Gunarsa, 2003: 182) terbagi menjadi tiga faktor yakni: pribadi, keluarga dan lingkungan.

a. Faktor Pribadi:

Pertama, Perasaan-perasaan tertekan dan beban yang tidak sanggup dipikulnya, seperti: (a) Tuntutan orang tua terhadap prestasi anak yang melebihi kemampuan dasar yang dimiliki anak, (b) Tuntutan perhadap anak agar anak dapat memperlihatkan prestasi-prestasi seperti yang diharapkan, padahal anak tidak bisa memenuhi karena masa perkembangannya belum siap, (c) Tekanan 
orang tua agar anak mengikuti berbagai kegiatan, (d) Kekecewaan anak karena tidak berhasil memasuki sekolah/jurusan yang dikehendaki dan tidak dinetralisasikan dengan baik oleh orang tua.

Kedua, Sikap menentang, sikap tidak mudah menerina saran/nasehat orang lain, sikap kompersatoris, yang kesemuanya bisa bersumber pada keadaan fisiknya. Ketiga, Anak menunjukkan perilaku orang tua tidak mampu menyesuaikan dari sumber penyebab karena tuntutannya yang berlebihan, tidak suka puas terhadap apa yang diperoleh atau diberikan orang tua.

Faktor pribadi mempengaruhi terjadinya perilaku kenakalan remaja, atau permasalahan yang dialami tidak dapat diatasi maka lama-kelamaan akan berkembang pada tindakan agresif, tindakan agresif merupakan salah satu bentuk dari perilaku kenakalan.

b. Faktor keluarga.

Orang tua berperan besar terhadap perkembangan kepribadian anak dan menjadi faktor penting dalam menanamkan dasar kepribadian seseorang setelah dewasa. Lingkungan rumah khususnya orang tua menjadi teramat penting sebagai tempat persemaian dari benih-benih yang akan tumbuh dan berkembang lebih lanjut. Buruk dialami dalam keluarga akan buruk pula diperlihatkan terhadap lingkungannya. Hubungan antar pribadi dalam keluarga yang meliputi pula hubungan antar saudara, hubungan suami istri menjadi faktor penting munculnya perilaku yang tergolong nakal.

c. Faktor Lingkungan Sosial dan Perubahannya.

Lingkungan sosial dengan berbagai ciri khususnya memegang peranan besar terhadap munculnya kenakalan, apabila tidak didukung oleh kepribadian dasar yang dibentuk dalam keluarga. Kesenjangan antar norma, ukuran, patokan dalam keluarga dengan lingkungannya perlu diperkecil agar tidak timbul keadaan tumpang tindih atau serba tidak menentu, suatu kondisi yang memudahkan munculnya perilaku tanpa kendali yaitu penyimpangan dari berbagai peraturan yang ada. Kegoncangan mudah timbul karena kita berhadapan dengan berbagai perubahan yang ada dalam masyarakat. Pengaruh pribadi terhadap pribadi lain dirumah maupun lingkungan luar rumah yang memungkinkan hubungan 
cukup sering terjadi akan mempengaruhi kehidupan pribadi, kehidupan keluarga dan kehidupan sosialnya.

Dari uraian ketiga faktor kenakalan remaja tersebut diatas penulis menyimpulkan bahwa kenakalan dipengaruhi tiga faktor yaitu: (1) Faktor pribadi adalah suatu penyebab yang timbul dari diri remaja. Contohnya: perasaan tertekan, beban yang tidak sanggup dipikulnya, sikap menentang terhadap orang lain, yaitu adanya tuntutan dari orang tua terhadap prestasi anak yang melebihi kemampuan dasar anak dan mengakibatkan kenakalan pada anak. Sikap menentang orang lain dilakukan karena anak menganggap orang lain tidak sesuai dengan dirinya, (2) Faktor keluarga adalah suatu penyebab yang timbul dari suasana keluarga apabila keluarga mempunyai hubungan tidak baik akan berpengaruh pada anak dan menyebabkan anak menjadi nakal, (3) Faktor lingkungan adalah suatu penyebab yang timbul dari lingkungan sosial. Contohnya perbedaaan antara norma keluarga dan norma lingkungan, pengaruh pribadi dengan lingkungan, percampuran antar corak kehidupan, adat-istiadat, nilai sikap. Apabila lingkungan terutama lingkungan yang negatif mempengaruhi anak maka menyebabkan anak berperilaku yang negatif pula atau nakal.

Menurut penulis konsep diri merupakan faktor pribadi yang dapat diduga berpengaruh terhadap perilaku kenakalan remaja. Sehubungan dengan itu Burns; mengemukakan pendapatnya bahwa konsep diri memiliki peran penting dalam menentukan perilaku, bagaimana individu memandang dirinya akan tampak pula dari seluruh perilakunya. Konsep diri yang negatif akan mempengaruhi perilaku yang negatif pula, setiap orang bertingkah laku sedapat mungkin sesuai konsep dirinya. Misalnya seorang berfikir dia nakal, individu tersebut akan benar-benar nakal. Ini karena individu tersebut berusaha hidup dengan label yang diletakkan pada dirinya.

\section{Analisis Data dan Pembahasan}

Dalam teknik analisis data yang digunakan untuk menganalisis skor angket adalah teknik analisis regresi satu prediktor menurut Sudjana (1996: 315) dengan rumus dan langkahnya sebagai berikut.

Rumus : $\mathrm{Y}=\mathrm{a}+\mathrm{bX}$ 
Konsep Diri Dan Pengaruhnya Terhadap Kenakalan Remaja ...

N. $\sum X Y-\left(\sum X\right)\left(\sum Y\right)$

Rumus : $\mathrm{b}=$

Rumus : $\mathrm{a}=$

N. $\sum \mathrm{X}^{2}-\left(\sum \mathrm{X}\right)^{2}$

Keterangan :

$\mathrm{Y} \quad=$ nilai $\mathrm{Y}$ yang dihitung

a = bilangan tetap yang dicapai

$\mathrm{bX}=$ bilangan tetap dari nilai $\mathrm{X}$

\section{1) Analisis Data}

Data dari skor angket Konsep Diri dan Kenakalan Remaja, masing-masing skor dihitung dengan analisis persentase menunjukkan sebagai berikut : Skor maksimal angket Konsep Diri adalah 30 item x $4=120$, apabila jumlah sampel 47 responden maka jumlah skor maksimal yaitu $120 \times 47=5640$. Skor riil yang diperoleh adalah 4381.

Rumus :

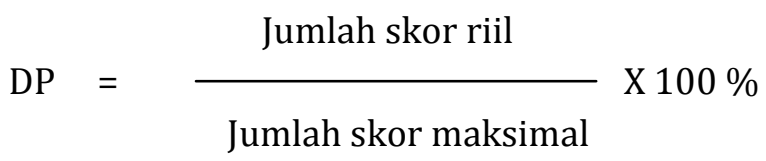

Jadi hasil persentase angket Konsep Diri adalah (4381:4640) x $100 \%=94,4 \%$. Setelah dikonsultasikan dengan tabel pedoman persentase menunjukkan bahwa dalam kategori sangat baik. Artinya Konsep Diri menunjukkan kategori sangat tinggi atau tingkatan sangat baik.

Skor maksimal hasil angket kenakalan remaja adalah 30 item x $4=120$, apabila jumlah sampel 47 responden maka jumlah skor maksimal yaitu $120 \times 47=5640$. Sedangkan skor riil yang diperoleh adalah 4393.

Jadi hasil persentase skor angket Kenakalan Remaja adalah (4393:5640) x 100\% = 77,9\%. Setelah dikonsultasikan dengan tabel 
pedoman persentase menunjukkan bahwa dalam kategori rendah. Artinya Kenakalan Remaja siswa dalam katagori rendah.

Sedangkan dalam perhitungan regresi satu prediktor $\mathrm{Y}=\mathrm{a}+$ bX.

$$
\begin{aligned}
& \text { Data diketahui sebagai berikut: } \\
& \begin{array}{lll}
\mathrm{N}=47 & \mathrm{X}=4381 & \mathrm{X}^{2}=419777 \\
\mathrm{XY}=419269 & \mathrm{Y}=4393 & \mathrm{Y}^{2}=420951
\end{array}
\end{aligned}
$$

Mencari koefisien a menggunakan rumus :

$$
\begin{aligned}
& a=\frac{\left(\sum Y\right)\left(\sum X^{2}\right)-\left(\sum X\right)\left(\sum X Y\right)}{N\left(\sum X^{2}\right)-\left(\sum X\right)^{2}} \\
& a=\frac{(4393 \times 419777)-(4381 \times 419269)}{(47 \times 419777)-(4381)^{2}}=\mathbf{1 3 , 5 4}
\end{aligned}
$$

Mencari koefisien b menggunakan rumus:

$$
\begin{aligned}
& \mathrm{b}=\frac{\mathrm{N} \cdot \sum \mathrm{XY}-\left(\sum \mathrm{X}\right)\left(\sum \mathrm{Y}\right)}{\mathrm{N} \cdot \sum \mathrm{X}^{2}-\left(\sum \mathrm{X}\right)^{2}} \\
& \mathrm{~b}=\frac{(47 \mathrm{X} 419269)-(4381 \mathrm{x} 4393)}{(47 \times 419777)-(4381)^{2}}=\mathbf{0 , 8 6}
\end{aligned}
$$

Persamaan regresi $\mathrm{Y}=13,54+0,86 \mathrm{X}$

\section{Mencari jumlah kuadrat (JK) sumber variasi}

$$
J K(T)=\sum y^{2}=420951
$$

$$
\left(\sum y\right)^{2}
$$


Konsep Diri Dan Pengaruhnya Terhadap Kenakalan Remaja ...

$$
\begin{aligned}
& \mathrm{JK}(\mathrm{a})=\frac{}{\mathrm{N}}=\frac{}{47}=\mathbf{4 1 0 6 0 5 , 3} \\
& \left(\sum \mathrm{x}\right)\left(\sum \mathrm{y}\right) \\
& \mathrm{JK}(\mathrm{b} / \mathrm{a})=\mathrm{b}\left\{\sum \mathrm{xy}-\longrightarrow\right. \\
& \text { (4381x4393) } \\
& =0,86\{419269- \\
& =\mathbf{8 3 8 6 , 0 2} \\
& \mathrm{JK}(\mathrm{s})=\mathrm{Jk}(\mathrm{T})-\mathrm{JK}(\mathrm{a})-\mathrm{JK}(\mathrm{b} / \mathrm{a}) \\
& =420951-410605,3-8386,02 \\
& =1959,68 \\
& \mathrm{RJK}(\mathrm{s})=\frac{\mathrm{JK}(\mathrm{s})}{\mathrm{N}-2}=\frac{1959,68}{47-2}=\mathbf{4 3 , 5 5}
\end{aligned}
$$

Hasil analisis pada taraf signifikansi $5 \%(27: 18)=2,11$, sedangkan $F_{\text {hitung }}=192,56$. Maka $F_{\text {hitung }}=192,56>F_{\text {tabel } 5 \%}(27: 18)=$ 2,11. Karena $\mathrm{F}_{\text {hitung }}$ lebih besar dari $\mathrm{F}_{\text {tabel, }}$ dapat disimpulkan bahwa antara variabel X (konsep diri) dan variabel Y (kenakalan remaja) adalah linier.

Tabel 3.

Analisis varians regresi X terhadap Y

\begin{tabular}{lcccc}
\hline Sumber Varians & Dk & JK & KT & F \\
\hline Total & 47 & 420951 & 420951 & \\
\hline Regresi (a) & 1 & 410605,3 & 410605,3 & \\
Regresi (b/a) & 1 & 8386,02 & 8386,02 & 192,56 \\
Residu (s) & 45 & 1959,68 & 1959,68 & \\
\hline Tuna cocok & 27 & 1479,08 & 54,78 & \\
Galat & 18 & 480,6 & 26,7 & \\
\hline
\end{tabular}

Karena $\mathrm{F}$ tabel 5\% (1:47) $=4,05$. Maka $\mathrm{F}$ hitung $=192,56>\mathrm{F}$ tabel $5 \%(1: 47)=4,05$. Sehingga dapat disimpulkan bahwa antara variabel X (konsep diri) dan variabel Y (kenakalan remaja) 
berpengaruh secara signifikan. Artinya semakin tinggi nilai score konsep diri berarti semakin rendah tingkat kenakalan remaja dan sebaliknya semakin rendah nilai score konsep diri maka akan semakin tinggi tingkat kenakalan remaja tersebut.

Sumbangan Efektif antara variabel $\mathrm{X}$ konsep diri) dan variabel Y (kenakalan remaja), diketahui sebagai berikut:

Rumus :

Diketahui :

$$
\mathrm{SE}=\frac{\mathrm{JK}(\mathrm{b} / \mathrm{a})}{\mathrm{JK}(\mathrm{tot})} \times 100 \%
$$

$$
\begin{aligned}
\mathrm{JK}(\mathrm{b} / \mathrm{a}) & =\mathbf{8 3 8 6 , 0 2} \\
\mathrm{JK}(\mathrm{tot}) & =\text { jumlah kuadrat total } \\
& =\sum \mathrm{y}^{2}-\frac{\left(\sum \mathrm{y}\right)^{2}}{\mathrm{~N}}=420951-\frac{(4393)^{2}}{47} \\
& =\mathbf{1 0 3 4 5 , 7} \\
\mathrm{SE} \quad & \frac{\mathrm{JK}(\mathrm{reg})}{\mathrm{JK}(\mathrm{tot})} \times 100 \%=\frac{8386,02}{10345,7} \times 100 \% \\
= & \mathbf{8 1 , 1} \%
\end{aligned}
$$

Jadi sumbangan efektif antara variabel X (Konsep Diri) dan variabel Y (Kenakalan Remaja) sebesar 81,1 \%

\section{2) Uji Hipotesis}

Hasil analisis yang menggunakan teknik analisis regresi satu prediktor, menunjukkan bahwa $\mathrm{F}_{\text {hitung }}=192,56>\mathrm{F}_{\text {tabel }} 5 \%(1 ;: 47)=$ 
4,05. Artinya antara variabel $\mathrm{X}$ (Konsep Diri) dan variabel $\mathrm{Y}$ (Kenakalan Remaja) berpengaruh secara signifikan pada taraf $5 \%$.

Berdasarkan hasil analisis, maka hipotesis penelitian yang berbunyi: Ada pengaruh positif dan signifikan Konsep Diri terhadap Kenakalan Remaja remaja pada siswa SMKN I Rembang klas II tahun pelajaran 2014/2015, diterima karena teruji kebenarannya.

\section{3) Hasil Kajian}

Hasil analisis penelitian dengan menggunakan teknik analisis regresi satu prediktor, yang mengungkap tentang pengaruh konsep diri terhadap perilaku kenakalan remaja pada siswa SMK N I Rembang tahun pelajaran 2014/2015, terhadap 47 siswa menunjukkan bahwa $\mathrm{F}$ hitung $=192,56$ sedangkan $\mathrm{F}_{\text {tabel }} 5 \%(1 ;: 47)$ $=4,05$.

Karena $\mathrm{F}_{\text {hitung }}=192,56>\mathrm{F}_{\text {tabel }} 5 \%(1 ;: 47)=4,05$ maka antara variabel X (konsep diri) dan variabel $Y$ (kenakalan remaja) berpengaruh secara signifikan pada taraf 5\%. Hal ini menunjukkan bahwa konsep diri berpengaruh secara signifikan terhadap perilaku kenakalan remaja pada siswa SMK N I Rembang tahun pelajaran 2014/2015. Sehingga hipotesis penelitian yang berbunyi : Ada pengaruh positif yang signifikan konsep diri terhadap perilaku kenakalan remaja pada siswa SMK N I Rembang tahun pelajaran 2014/2015, diterima karena teruji kebenarannya.

Diterimanya hipotesis penelitian ini didukung oleh data ratarata score angket hasil analisis persentase angket penelitian yang menunjukkan bahwa hasil persentase angket konsep diri adalah 80,8\%. Artinya konsep diri siswa memiliki kategori tinggi. Sedangkan hasil persentase angket kenakalan remaja adalah 81,3\%. Artinya perilaku kenakalan remaja siswa dalam katagori agak rendah. Dapat pula dikatakan bahwa semakin tinggi nilai score konsep diri berarti semakin rendah tingkat kenakalan remaja dan sebaliknya semakin rendah nilai score konsep diri maka akan semakin tinggi tingkat kenakalan remaja tersebut.

Teori konsep diri memandang kepribadian individu terdiri dari tiga komponen yaitu citra diri, diri ideal dan harga diri. Peneliti lain telah menguatkan penelitian ini sehingga sekarang pendekatan ini terbukti meyakinkan ( Davies \& Brember, 1999). Davies dan Brember melaporkan hasil penelitian selama delapan tahun yang 
mengukur harga diri menunjukkan korelasi yang signifikan antara harga diri dan semua skor keberhasilan.

Konsep diri seseorang adalah istilah yang membawahi ketiga aspek pengembangan diri tersebut di atas. Konsep diri adalah kesadaran seseorang atas apa yang dia miliki. Hal tersebut merupakan kesadaran tentang identitas yang ia miliki. Kerumitan dan kealamiahan konsep diri sudah menjadi pemikiran para ahli filsafat selama berabad-abad dan sudah tidak dianggap menjadi topik yang baru dalam psikologi. James (1990) yang memperbarui kembali pengertian bidang filsafat. Para ahli filsafat pada jamannya, James, berusaha dengan keras menentukan tujuan dalam hal "Self" (diri) dan "Me" (aku), "The I" (aku), dan akhirnya disimpulkan bahwa hal itu benar, masuk akal. Para ahli psikologi mempelajari The Self sebagai perwujudan dari tujuan James untuk menggambarkan perkembangan bayi sampai satu tahun. Pada akhir dewasa dikatakan sebagai Self Conciouses (kesadaran diri). Proses dari seluruh perkembangan dapat dipertimbangkan melalui sebuah proses menjadikan ciri-ciri/ sifat-sifat yang dimilikinya.

Terbuktinya hipotesis penelitian menunjukkan bahwa konsep diri terhadap perilaku kenakalan remaja pada siswa SMK N I Rembang tahun pelajaran 2014/2015 telah menunjukkan bahwa konsep diri memandang kepribadian individu terdiri dari tiga komponen yaitu citra diri, diri ideal dan harga diri yang menunjukkan tentang pentingnya nilai control diri seorang siswa yang mengarah pada perilaku kenakalan remaja sangatlah beralasan.

\section{Simpulan}

Berpijak pada hasil pembahasan dalam penelitian ini, maka hasil penelitian dapat disimpulkan sebagai berikut : (1) Hasil persentase rata-rata angket konsep diri menunjukkan 80,8\%. Artinya konsep diri siswa menunjukkan kategori tinggi/baik, (2) Hasil persentase angket kenakalan remaja menunjukkan 81,3\%. Artinya kenakalan remaja siswa dalam katagori agak rendah, (3) $\mathrm{F}$ hitung $=$ $192,56>\mathrm{F}$ tabel $5 \%(1 ; 47)=4,05$ artinya antara variabel $\mathrm{X}$ (konsep diri) dan variabel $Y$ (kenakalan remaja) berpengaruh secara signifikan pada taraf 5\%. Maka hipotesis penelitian yang berbunyi: 
Konsep Diri Dan Pengaruhnya Terhadap Kenakalan Remaja ...

Ada pengaruh positif yang signifikan konsep diri terhadap kenakalan remaja pada siswa SMK N I Rembang tahun pelajaran 2014/2015, diterima karena teruji kebenarannya, besarnya pengaruh $81,1 \%$. 


\section{DAFTAR PUSTAKA}

Abraham, Amit. 2007. Mengupas Kepribadian Anda. Jakarta: PT. Buana Ilmu Populer.

Anwar, Saifuidin. 2000. Pengukuran Skala Psikologi. Yogyakarta: Pustaka Pelajar.

Dirga Gunarsa, Singgih. 1990. Psikologi Remaja. Jakarta: Rineka Cipta Hadi, Sutrisno. 1987. Metodologi Research Jilid 3. Yayasan Penerbitan Fakultas Psikologi Universitas Gajah Mada.Yogyakarta.

Hadi, Sutrisno. 1995. Statistik II. Yogyakarta: Andi Offset.

Hajar, Ibnu. 1996. Dasar-Dasar Metodologi Penelitian Kwantitatif Dalam Pendidikan. Jakarta: PT Raja Grafindo Persada.

Hutagalung, Inge. 2007. Pengembangan Kepribadian. Jakarta: PT. Indeks

Jawa Pos. 20 November 2014. Mampir Warung Empat Pelajar Diamankan Semarang.

Kartono, Kartini. 1992. Patologi Sosial 2 Kenakalan Remaja. Jakarta: Grafindo Persada.

Margono, S. 2004. Metodologi Penelitian Pendidikan. Jakarta: Rineka Cipta.

Marppiare, Andi. 1982. Psikologi Remaja. Jakarta: Usaha Nasional Nasir. 2003. Metode Penelitian. Jakarta: Gralia Indonesia.

R. Fraenkel, Jack \& Norman E. Wallen. 1993. How To Design And Evaluate Research In Education. New York: McGraw-Hill Inc.

Rahmad, Jalaluddin. 1999. Psikologi Komunikasi. Bandung: Remaja Rosda Karya.

Santosa, Singgih. 2001. SPSS Versi 10 Mengolah Data Statistik Secara Profesional. Jakarta: PT Elex Media Komputindo Kelompok Gramedia.

Subana, M. dkk. 2000. Statistik Pendidikan.. Bandung: Pustaka Setia Sudarsono. 2001. Kenakalan Remaja. Jakarta: Remaja Cipta.

Sugiyono. 2001. Metode Penelitian Administrasi. Bandung: Alfabeta. Sujana. 1996. Metoda Statistika. Bandung: Transito.

Syah, Muhibbin. 1995. Psikologi Pendidikan. Bandung: Remaja Posdakarya.

Wibisono, Yusuf. 2005. Metode Statistik. Yogyakarata: Gajah Mada University Press. 
Konsep Diri Dan Pengaruhnya Terhadap Kenakalan Remaja ...

Winarsunu, Tulus. 2004. Statistik Dalam Penelitian Psikologi dan Pendidikan. Malang: UMM Press (Penerbitan Universitas Muhammadiyah Malang).

Wirawan Sarwono, Sarlito. 2003. Psikologi Remaja. Jakarta: Rajawali Press. 